This Accepted Author Manuscript is copyrighted and published by Elsevier. It is posted here by agreement between Elsevier and University of Brasilia. Changes resulting from the publishing process - such as editing, corrections, structural formatting, and other quality control mechanisms - may not be reflected in this version of the text. The definitive version of the text was subsequently published in [Theriogenology, Volume 67, Issue 8, May 2007, Pages 13071315, doi:10.1016/j.theriogenology.2007.01.015].You may download, copy and otherwise use the AAM for non-commercial purposes provided that your license is limited by the following restrictions:

(1) You may use this AAM for non-commercial purposes only under the terms of the CC-BY-NCND license.

(2) The integrity of the work and identification of the author, copyright owner, and publisher must be preserved in any copy.

(3) You must attribute this AAM in the following format: [agreed attribution language, including link to CC BY-NC-ND license + Digital Object Identifier link to the published journal article on Elsevier's ScienceDirect ${ }^{\circledR}$ platform].

Este Manuscrito do Autor Aceito para Publicação (AAM) é protegido por direitos autorais e publicado pela Elsevier. Ele esta disponível neste Repositório, por acordo entre a Elsevier e a Universidade de Brasília. As alterações decorrentes do processo de publicação - como a edição, correção, formatação estrutural, e outros mecanismos de controle de qualidade - não estão refletidas nesta versão do texto. A versão definitiva do texto foi posteriormente publicado em [Theriogenology, Volume 67, Número 8, Maio 2007, Páginas Pages 1307-1315 doi:10.1016/j.theriogenology.2007.01.015]. Você pode baixar, copiar e utilizar de outra forma o AAM para fins não comerciais, desde que sua licença seja limitada pelas seguintes restrições:

(1) Você pode usar este AAM para fins não comerciais apenas sob os termos da licença CC- BYNC-ND.

(2) A integridade do trabalho e identificação do autor, detentor dos direitos autorais e editor deve ser preservado em qualquer cópia.

(3) Tem de atribuir este AAM no seguinte formato: [acordo na linguagem atribuída, incluindo o link para CC BY-NC-ND licença Digital + DOI do artigo publicado na revista Elsevier ScienceDirect ${ }^{\circledR}$ da plataforma]. 


\title{
Effects of freeze-drying on cytology, ultrastructure, DNA fragmentation, and fertilizing ability of bovine sperm
}

\author{
C.F. Martins \\ S.N. Báo \\ M.N. Dode \\ G.A. Correa \\ R. Rumpf
}

\begin{abstract}
Freeze-drying sperm is an alternative to cryopreservation. Although sperm from various species has been freeze-dried, there are few reports for bovine sperm. The primary objective of this study was to evaluate the protective effect of various freeze-drying media on the structural and functional components of bovine sperm. The media tested were composed of TCM 199 with Hanks salts supplemented with 10\% fetal calf serum (FCS) and TCM 199 with Hanks salts supplemented with $10 \%$ FCS and $0.2 \mathrm{M}$ trehalose and EGTA solution. The efficiency of each medium on the preservation of freeze-dried sperm structures was evaluated with conventional and electron microscopy, DNA integrity was analyzed by a TUNEL assay, and fertilizing ability of lyophilized sperm was determined with ICSI. Although the plasma membrane was damaged in all media tested, mitochondria were similarly preserved in all freeze-drying treatments. The acrosome was best preserved in the media that contained trehalose (other treatments also conserved this structure). In contrast, media containing EGTA or trehalose most effectively preserved the nuclei in freeze-dried sperm, with only 2 and 5\%, respectively, of cells with fragmented DNA. Furthermore, sperm conserved with these media also had higher $(P<0.05)$ rates of sperm head decondensation $(32.5$ and $27.5 \%)$, pronucleus formation (37.5 and 45.0\%) and blastocyst formation (19.4 and 18.3\%) than medium supplemented with FCS (15.0, 20.0 and 10.2\%, respectively). In conclusion, media with EGTA and trehalose adequately protected bovine sperm during freeze-drying by preserving the viability of their nuclei.
\end{abstract}

Keywords: Bovine; ICSI; Freeze-drying; Sperm preservation; TUNEL

\section{Introduction}

Freeze-drying (lyophilization), was developed to preserve bioactive molecules (DNA, enzymes, and proteins), pharmaceuticals products (antibiotics) and other delicate, solventimpregnated materials [1] and [2]. It has also been used to preserve cells, due to its ability to restrict active water by ice sublimation [3].

Freeze-drying sperm has been the focus of many research groups. Relative to conventional cryopreservation, freeze-drying is cheaper, uses no liquid nitrogen, requires less space for gamete storage, and is an easier and cheaper method of transporting sperm. The first attempt to preserve mammalian sperm by dehydration was reported by Polge et al. [3] using fowl sperm; after rehydration, the sperm were motile but their fertilizing ability was not 
evaluated. Subsequent efforts to lyophilize human and bovine sperm yielded very poor results [4] and [5]. In 1957, Yushchenko [6] reported for the first time the birth of a domestic animal following Al of freeze-dried rabbit sperm. Subsequent production of offspring with freezedried sperm has only been reported following the use of ICSI [7] and [8]. These results provided new possibilities to store and transport dehydrated gametes at room temperature or at $4{ }^{\circ} \mathrm{C}$, with many benefits for preservation of male gametes from laboratory and farm animals [9].

One of the main concerns with any preservation method is the extent of cellular damage. Regardless of the specific protocol used, cryopreservation of sperm reduces both motility and fertilizing ability [10]. Although freeze-drying is much more deleterious to sperm (than cryopreservation) and induces substantial loss of fertilizing ability, live offspring were obtained when freeze-dried sperm from mouse [7] and rabbit [8] were used for ICSI. Therefore, despite substantially reduced motility, cells remained viable, based on the fact that sperm nucleus and centrosome integrity are essential for the success of ICSI [11].

Efforts to preserve sperm structural integrity during cryopreservation have been made by testing various protector substances, e.g. albumin [7] and [12], EGTA solution [13] and [14] and trehalose [15]. However, it is not clear how freeze-drying affects specific components of sperm cells. The primary objective of the present study was to determine how the structural and functional components of bovine sperm were affected when various freeze-drying media containing these protective substances were used.

\section{Materials and methods}

\subsection{Animals}

All semen samples were obtained from one Nelore bull with semen previously tested for in vitro fertilization in our laboratory. In a pre-experiment, semen samples from three bulls were tested for Iyophilization. Freeze-dried sperm with different lyophilization media were evaluated by the acridine orange test (AOT) for chromatin integrity and by trypan blue-giemsa stain for acrosome integrity. Since sperm characteristics were similar for all three bulls (Table 1), to facilitate comparisons of embryo development, we selected one bull as the source of all semen used in the experiment. 
Table 1

Percentage of bovine sperm cells with intact chromatin and an intact acrosome in semen from three bulls that was freeze-dried in TCM Hank's supplemented with fetal calf serum (T1), trehalose (T2), and EGTA solution (T3)

\begin{tabular}{llllllll}
\hline Bull & \multicolumn{3}{c}{ Intact chromatin (\%) } & & \multicolumn{3}{c}{ Intact acrosome (\%) } \\
\cline { 2 - 3 } \cline { 7 - 8 } & $\mathrm{T} 1$ & $\mathrm{~T} 2$ & $\mathrm{~T} 3$ & & $\mathrm{~T} 1$ & $\mathrm{~T} 2$ & $\mathrm{~T} 3$ \\
\hline 1 & 97 & 100 & 100 & & 88 & 90 & 89 \\
2 & 95 & 100 & 100 & & 83 & 91 & 87 \\
3 & 98 & 100 & 100 & & 85 & 93 & 90 \\
\hline
\end{tabular}

There were no significant differences among bulls or treatments

\subsection{Solution for freeze-drying sperm}

All reagents, unless otherwise stated, were purchased from Sigma Chemicals (St. Louis, MO, USA). The different freeze-drying media tested were: Medium 1: TCM 199 with Hank's salts (Gibco Life Technologies Inc., Grand Island, NY, USA) supplemented with 10\% (v/v) FCS (Gibco Life Technologies Inc.); Medium 2: TCM 199 with Hanks salts supplemented with 10\% $(\mathrm{v} / \mathrm{v})$ fetal calf serum and $0.2 \mathrm{~mol} / \mathrm{L}$ trehalose; Medium 3: $10 \mathrm{mmol} / \mathrm{L}$ Tris $-\mathrm{HCl}$ buffered supplemented with $50 \mathrm{mmol} / \mathrm{L}$ of each of $\mathrm{NaCl}$ and $\mathrm{EGTA}$ [ethylene glycol-bis ( $\beta$-aminoethyl ether)- $\mathrm{N}, \mathrm{N}, \mathrm{N}^{\prime} \mathrm{N}^{\prime}$-tetraacetic acid] and $\mathrm{pH}$ of final solution adjusted to 8.2. Media 1,2 and 3 were considered as Treatments 1, 2 and 3, respectively.

\subsection{Experimental design}

Immediately after collection, motility was evaluated subjectively using light microscopy, morphology by phase contrast microscopy, and concentration by counting cells in a hemocytometer. Only semen samples with $>80 \%$ motility and $<10 \%$ morphologically abnormal sperm were used for the experiment. Each ejaculate was divided into two portions. One portion was cryopreserved with egg yolk Tris glycerol extender [16] with a total concentration of $30 \times 106 \mathrm{sperm} / 0.5 \mathrm{~mL}$ and was used as the control group. The other portion was centrifuged in a percoll gradient (45-90\%), to remove seminal plasma. Subsequently, sperm was washed twice in Tyrode's albumen lactate pyruvate (TALP) [17], and allocated into the three freeze-drying treatments (Treatments 1, 2 and 3). Samples from all treatments were submitted to freeze-drying process under the same conditions, were stored for 3 months at 4 ${ }^{\circ} \mathrm{C}$, and then rehydrated and sperm were evaluated by light, electron and fluorescence microscopy. In addition, sperm from different treatments were microinjected into matured oocytes to evaluate embryo developmental potential. 


\subsection{Sperm freeze-drying}

For all treatments, the concentration was adjusted to $10 \times 106$ sperm/100 $\mu \mathrm{L}$ freezedrying solution. Samples were diluted, placed in tubes of $1.5 \mathrm{~mL}$ and kept at room temperature for $30 \mathrm{~min}$. Then, sperm were cooled in liquid nitrogen vapor (approximately $-80^{\circ} \mathrm{C}$ for $1 \mathrm{~h}$ ), by keeping the tubes at a distance of $5 \mathrm{~cm}$ from liquid nitrogen surface before plunged into it. Frozen samples were immediately inserted into the freeze-drying machine (Thermo Savant, Holbrook, NY, USA), previously stabilized at $-40^{\circ} \mathrm{C}$ and $350 \times 10-3$ Mbar pressure. After 12-16 $h$ of freeze-drying, the tubes containing the samples were well covered with aluminum foil and stored for 3 months at $4{ }^{\circ} \mathrm{C}$.

\subsection{Rehydration}

Freeze-dried sperm samples were rehydrated by adding $100 \mu \mathrm{L}$ of milli-Q water at room temperature.

\subsection{Plasma membrane and acrosome integrity}

Before and after freeze-drying, integrity of the sperm membrane and acrosome was assessed by light microscopy following Didion et al. [18] with slight modifications. A sample of $20 \mu \mathrm{L}$ from each treatment suspension was incubated with $20 \mu \mathrm{L}$ of trypan blue stain $(0.2 \%)$ at $37^{\circ} \mathrm{C}$ for $10 \mathrm{~min}$, and then centrifuged twice at $700 \times \mathrm{g}$ for $6 \mathrm{~min}$. The pellet was re-suspended with $0.5 \mathrm{~mL}$ of TALP, three smears were made from each sample, fixed with methanol for 5 min, dried and stained overnight with Giemsa (10\%). Slides were evaluated by counting 200 cells in bright field microscopy and the results were expressed as percentage of cells with an intact acrosome.

\subsection{Ultrastructural assessment}

To confirm the observations obtained in light microscopy and to evaluate sperm ultrastructure, transmission electron microscopy was done on samples from all treatments. Sperm of each treatment were fixed for $3 \mathrm{~h}$ at room temperature in a solution containing $2 \%$ glutaraldehyde, $2 \%$ paraformaldehyde, $5 \%$ sucrose and $5 \mathrm{mM} \mathrm{CaCl} 2$ in $0.1 \mathrm{M}$ sodium cacodylate buffer, pH 7.2. After fixation, the specimens were rinsed in buffer, and post-fixed (1 
h) in $1 \%$ osmium tetroxide, $0.8 \%$ potassium ferricyanide, $5 \mathrm{mM} \mathrm{CaCl} 2$ in $0.1 \mathrm{M}$ sodium cacodylate buffer. Dehydration was carried out in acetone and embedding in Epon 812 resin. Ultrathin sections were stained with uranyl acetate and lead citrate, and examined in a JEOL 1011 (JEOL, Tokyo, Japan) transmission electron microscope, operating at $80 \mathrm{kV}$. All electron microscopy reagents were purchased from Electron Microscopy Sciences (Ft. Washington, PA, USA).

\subsection{Evaluation of chromatin integrity by acridine orange test}

For acridine orange staining, three smears from each sample were prepared on glass slide and air-dried. Each smear was fixed overnight in Carnoy's solution, freshly prepared with methanol and glacial acetic acid (3:1 ratio). The slides were air-dried again, and incubated in tampon solution ( $80 \mathrm{mmol} / \mathrm{L}$ citric acid and $15 \mathrm{mmol} / \mathrm{L} \mathrm{Na2HPO} 4, \mathrm{pH} 2.5$ ) at $75{ }^{\circ} \mathrm{C}$ for $5 \mathrm{~min}$ to test the chromatin stability. Then, the slides were stained with acridine orange stain $(0.2$ $\mathrm{mg} / \mathrm{mL}$ ). The slides were washed with water to remove background staining and while still wet, they were covered with coverslips and evaluated using epifluorescence microscope (Axiophot Zeiss; $490 \mathrm{~nm} / 530 \mathrm{~nm}$ excitation/barrier filter). A total of 100 cells were analyzed for each treatment slide. Sperm with normal DNA content had green fluorescence, whereas sperm with an abnormal DNA content emitted fluorescence in a spectrum varying from yellow-green to red. The percentage of sperm with intact chromatin was calculated by dividing the number of green-stained sperm by the total number of sperm and multiplying by 100 .

\subsection{Detection of DNA fragmentation by TUNEL assay}

For the TUNEL technique, we used the in situ Cell Death Detection Kit, fluorescein, carried out according to manufacturer's (Roche Diagnostics $\mathrm{GmbH}$, Mannheim, Germany) protocol with slight modifications. Sperm were washed in $100 \mu \mathrm{L}$ of phosphate-buffered saline (PBS) supplemented with $0.1 \%$ polyvinylpyrrolidone (PVP). Sperm suspension was fixed with $100 \mu \mathrm{L}$ of $4 \%$ paraformaldehyde for $1 \mathrm{~h}$ at room temperature. Cells were washed again in PBS supplemented with PVP $0.1 \%$ and permeabilized with $0.5 \%$ Triton X-100 in $0.1 \%$ sodium citrate for $1 \mathrm{~h}$ on ice. Then, permeabilized sperm were washed once in PBS supplemented with PVP $0.1 \%$ and incubated with the TUNEL reaction mixture containing terminal deoxynucleotidyl transferase (TdT) plus dUTP label in the dark at $37{ }^{\circ} \mathrm{C}$ for $1 \mathrm{~h}$. After labeling, the cells were washed in PBS with PVP $0.1 \%$ and counterstained with $5 \mu \mathrm{g} / \mathrm{mL}$ Hoechst 33342 to visualize 
total DNA. Negative (omitting TdT from the reaction mixture) and positive (using only DNAse I, $1 \mathrm{mg} / \mathrm{mL}$ for $30 \mathrm{~min}$ at room temperature) controls were performed in each sample. For each sample tested, at least 100 cells were analyzed using a fluorescence microscope. Each spermatozoon was assigned to contain either a normal (blue nuclear fluorescence due to Hoechst 33342) or a fragmented DNA (green nuclear fluorescence). The final percentage of sperm with fragmented DNA was referred to as TUNEL positive (\%).

\subsection{Gametes preparation for ICSI}

Oocytes were recovered from abbatoir-derived ovaries and matured for $22 \mathrm{~h}$ in medium composed of TCM 199 with Earle's salts, supplemented with FCS 10\% (v/v), $24 \mathrm{IU} / \mathrm{mL}$ of $\mathrm{LH}, 10 \mu \mathrm{g} / \mathrm{mL}$ of $\mathrm{FSH}$ and antibiotics (50 IU/mL penicillin and $50 \mu \mathrm{g} / \mathrm{mL}$ streptomycin). Matured oocytes were then exposed to $1 \mathrm{mg} / \mathrm{mL}$ of bovine hyaluronidase for $5 \mathrm{~min}$ to remove the cumulus cells. Denuded oocytes with evident polar body were transferred back to maturation medium and maintained in the incubator until microinjection.

Freeze-dried sperm samples were rehydrated and washed twice by centrifugation for 3 min at $700 \times g$ in TALP medium, where they remained until their use for ICSI. The frozen semen samples used as a control were prepared by centrifugation for $20 \mathrm{~min}$ at $700 \times \mathrm{g}$ in a percoll gradient (45 to $90 \%$ ) [17]. The selected sperm obtained after percoll were capacitated by incubation with $200 \mu \mathrm{g} / \mathrm{mL}$ of heparin for $1 \mathrm{~h}$, before being used for ICSI.

\subsection{Sperm microinjection}

Sperm microinjection was performed by using a micromanipulator (Narishige Instrument, Tokyo, Japan) connected to an inverted microscope (Nikon, Japan) in a 200x magnification. Dishes for microinjection were prepared by adding 10 drops of $20 \mu \mathrm{L}$ of TCM 199 with Hanks salts and 25 mM HEPES, FCS $(10 \%, v / v)$ and antibiotics in the periphery of the dish and 4 drops of $10 \%$ polyvinylpyrrolidone (PVP) solution (Irvine Scientific, Santa Ana, CA, USA) containing the sperm in the center of the dish. The selected spermatozoon had its tail broken by pressing the injection pipette against the bottom of the Petri dish. The spermatozoon with a broken tail was then aspirated into the injection pipette and transferred to the drop containing the oocytes. The tip of the pipette was introduced into the perivitelline space and the oolemma was ruptured by gently aspirating small amounts of the ooplasm into the pipette. Then, the spermatozoon and the small amount of the aspirated cytoplasm were 
inserted back into the oocyte with a minimal volume of PVP solution. Sham injections were performed in a similar manner for the parthenogenetic control.

\subsection{Oocyte activation and embryo culture}

All microinjected oocytes from each treatment were cultured for $1 \mathrm{~h}$ in SOF medium [19], until activation time. For activation oocytes were exposed to a $5 \mu \mathrm{M}$ of ionomycin solution for $5 \mathrm{~min}$ and then were transferred to SOF medium supplemented with $6 \mathrm{mg} / \mathrm{mL}$ of BSA fatty acid free, where they remained for $5 \mathrm{~min}$ to stop activation. After activation oocytes were cultured in SOF medium for $4 \mathrm{~h}$ for extrusion of the second polar body and finally incubated in a solution of $1.9 \mathrm{mM}$ 6-dimethylaminopurine (DMAP) for $4 \mathrm{~h}$. Activated oocytes were cultured in SOF medium, using a co-culture with cumulus cells under mineral oil at $39^{\circ} \mathrm{C}$ with $5 \% \mathrm{CO} 2$ in air.

\subsection{Evaluation of decondensed sperm head, pronucleus formation and embryonic development}

A total of 165 oocytes were removed from culture at $16-18 \mathrm{~h}$ post-ICSI, fixed overnight in methanol: acetic acid $(3: 1, \mathrm{v} / \mathrm{v})$ and stained with $1 \%$ of acetic acid lacmoid. Then, the

oocytes were examined with phase-contrast microscopy to verify the presence of a decondensed sperm head and pronucleus formation. Embryonic development was assessed 2 days (cleavage) and 7 days (blastocyst rate) after the start of culture.

\subsection{Statistical analysis}

All data were submitted to a normality test before analysis. One-way ANOVA was used to compare the effects of various freeze-drying treatments. The data are given as mean values \pm S.D. When ANOVA revealed a significant effect, the treatments were compared by a HolmSidak test using Sigma Stat for Windows Version 3.11 (Systat Software, Inc., Richmond, California, USA). A difference of $\mathrm{P}<0.05$ was considered significant. 


\section{Results}

\subsection{Pre-experiment results}

All sperm (100\%) from the three bulls evaluated had a damaged plasma membrane, regardless of the protector medium utilized. There were no differences $(P>0.05)$ among bulls or treatments for chromatin and acrosome integrity ( Table 1).

\subsection{Evaluation of optical microscopy}

Although fresh semen had an average of $90 \%$ motile sperm, dilution with freeze-drying media reduced sperm motility. Ten minutes after dilution, motility was 80,30 and $40 \%$ for treatments Treatments 1, 2 and 3, respectively. After $30 \mathrm{~min}$, no further change in the motility for Treatment 1 was noted, whereas in Treatments 2 and 3, all cells were immotile. Indeed after freeze-drying and rehydration, all sperm were immotile and were stained as dead (by the trypan blue-giemsa stain), due to breakage of the plasma membrane.

Sperm from Treatments 1 and 2 were easily diluted and dispersed by the use of milli-Q water. In contrast, those from Treatment 3 were strongly agglutinated, being very difficult to dissolve, even after repeated pipetting.

Although there was a tendency $(P<0.10)$ for the percentage of sperm with tail separated from the head to be higher in Treatment 1 (8\%) versus Treatment 2 (5\%), Treatment $3(6 \%)$ and control (3\%), no differences were detected among then $(P>0.05)$. The percentage of sperm cells with an intact acrosome in Treatment $2(92 \%)$ was similar $(P>0.05)$ to the control group (95\%), but higher $(P<0.05)$ than in Treatments $1(75 \%)$ and $3(85 \%)$.

\subsection{Ultrastructural assessment}

Electron microscopy (Table 2) confirmed the results obtained by optical microscopy in regard to plasma membrane and acrosome integrity. The sperm cell component most affected by freeze-drying was the plasma membrane (Fig. 1A-D), which was damaged in all treatments, differing from the control (Fig. 1E and F). Microtubules organization was also compromised in the majority of the sperm from Treatments 2 and 3 (Fig. 1), diverging from Treatment 1 (Fig. 1B) and control (Fig. 1F), in which microtubules were intact. Conversely, the acrosome and 
mitochondria were well preserved in all treatments; in that regard, sperm preserved with trehalose had more intact acrosomes (Fig. 1A-F).

Table 2

Ultrastructural evaluation of the principal components of bovine sperm, following freezedrying using dilution media supplemented with fetal calf serum, trehalose, or EGTA solution (Treatments 1, 2 and 3, respectively)

\begin{tabular}{lllll}
\hline Treatment & Membrane & Acrosome & Mitochondria & Microtubules \\
\hline 1 & Damaged & Intact & Intact & Intact \\
2 & Damaged & Intact & Intact & Damaged \\
3 & Damaged & Intact & Intact & Damaged \\
Control & Intact & Intact & Intact & Intact \\
\hline
\end{tabular}

The control treatment was frozen-thawed semen from the same bull.

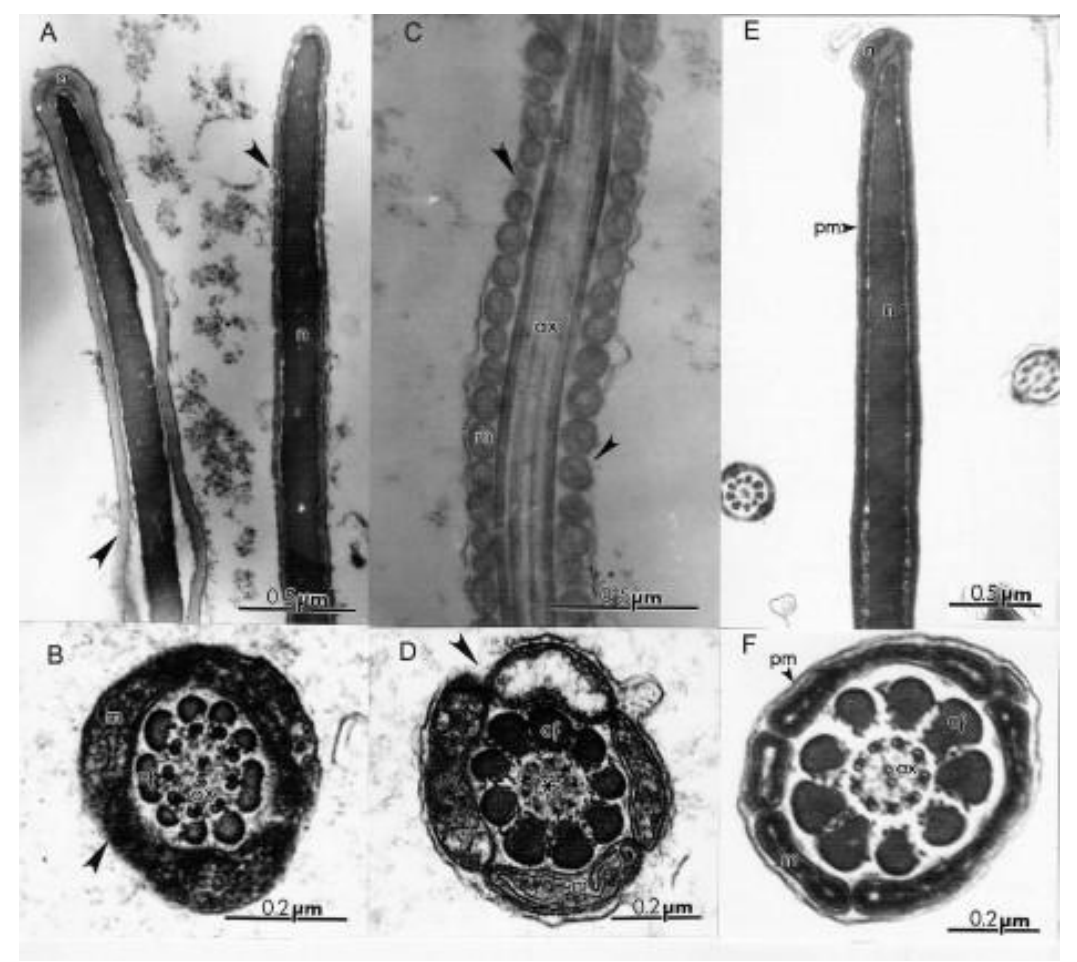

Fig. 1. Electron micrographs showing freeze-dried sperm: (A) sperm from T3 with damaged plasma membrane (arrowhead) and intact acrosome (a) and nucleus (n); (B) sperm from Treatment 2 with damaged plasma membrane (arrowhead), presence of intact mitochondria (m) and axoneme (ax); (C) sperm from Treatment 1 with damaged plasma membrane ( $\mathrm{pm}$, arrowhead), presence of intact mitochondria (m), coarse fibers (cf) and axoneme (ax); (D) sperm from Treatment 2 with disorganized microtubules (*); (E and F) frozen sperm (control) with well-preserved ultrastructure.

\subsection{DNA fragmentation assay}

The TUNEL assay was used to assess differences in DNA damage among treatments. Treatment 3 had the lowest rate of DNA fragmentation (2\%), not significantly different from the control. Treatment 2 had 5\% of the cells with DNA fragmentation, which was higher than 
both Treatment 3 and the control, but lower than Treatment 1 . The highest $(P<0.05)$ DNA damage rate (14\%) was present in Treatment 1.

\subsection{Development of oocytes after ICSI}

The functionality of the freeze-dried sperm nucleus (assessed by ICSI) is shown in Table 3 and Table 4. When matured oocytes were microinjected with sperm from Treatments 2 and 3 , the proportion of oocytes with sperm head decondensation and pronuclear formation, was similar $(P>0.05)$, but superior $(P<0.05)$ to Treatment 1 . Similarly, the rate of development to the blastocyst stage was similar $(P>0.05)$ for the control and Treatments 2 and 3 , but superior $(P<0.05)$ to Treatment 1 and the parthenogenetic control (sham injection).

Table 3

Number and percentage of bovine oocytes (combined for five replicates) with an intact sperm head (ISH), sperm head decondensation (DH) and pronucleus formation (PN) after ICSI using frozen-thawed spermatozoa (control) and spermatozoa lyophilized with freeze-drying media supplemented with fetal calf serum, trehalose, or EGTA solution (Treatments 1, 2 and 3, respectively)

\begin{tabular}{lllcrr}
\hline Treatment & No. of oocytes & ISH & ISH + IPN & DH + IPN & 2PN \\
\hline 1 & 40 & $9(22.5 \%)$ & $17(42.5 \%)$ & $6(15.0 \%)^{\mathrm{b}}$ & $8(20.0 \%)^{\mathrm{a}}$ \\
2 & 40 & $5(12.5 \%)$ & $6(15.0 \%)$ & $11(27.5 \%)^{\mathrm{a}}$ & $18(45.0 \%)^{\mathrm{b}}$ \\
3 & 40 & $10(25.0 \%)$ & $2(5.0 \%)$ & $13(32.5 \%)^{\mathrm{a}}$ & $15(37.5 \%)^{\mathrm{b}}$ \\
Control & 45 & $11(24.4 \%)$ & $4(8.8 \%)$ & $5(11.1 \%)^{\mathrm{b}}$ & $25(55.5 \%)^{\mathrm{e}}$ \\
\hline
\end{tabular}

( $a$ and $b$ ) Within a column, values without a common superscript differ $(P<0.05)$.

Table 4

Embryonic development (combined for 10 replicates) after ICSI using frozen-thawed spermatozoa (control), sham injection (parthenogenetic control) and spermatozoa lyophilized with freeze-drying media supplemented with fetal calf serum, trehalose, or EGTA solution (Treatments 1, 2 and 3, respectively)

\begin{tabular}{llrl}
\hline Treatment & $\begin{array}{l}\text { No. of } \\
\text { oocytes }\end{array}$ & $\begin{array}{l}\text { No. of } \\
\text { cleaved }(\%)\end{array}$ & $\begin{array}{l}\text { No. of } \\
\text { blastocysts } \\
(\%)\end{array}$ \\
\hline 1 & 185 & $67(36.2 \%)^{\mathrm{a}}$ & $19(10.2 \%)^{\mathrm{a}}$ \\
2 & 185 & $93(50.2 \%)^{\mathrm{b}}$ & $34(18.3 \%)^{\mathrm{b}}$ \\
3 & 180 & $104(57.7 \%)^{\mathrm{C}}$ & $35(19.4 \%)^{\mathrm{b}}$ \\
Frozen-thawed semen & 185 & $99(53.5 \%)^{\mathrm{c}}$ & $38(20.5 \%)^{\mathrm{b}}$ \\
Sham injection & 160 & $52(32.5 \%)^{\mathrm{a}}$ & $13(8.1 \%)^{\mathrm{a}}$ \\
\hline
\end{tabular}

(a-c) Within a column, values without a common superscript differ $(P<0.05)$.

\section{Discussion}

In the present study, we have generated novel data regarding the extent that various freeze-drying media preserved the structural and functional characteristics of the bovine sperm. We demonstrated for the first time that EGTA solution, which is widely used in mice [2], [3], [4], [5], [6], [7], [8], [9], [10], [11], [12], [13] and [14], efficiently preserved the nucleus, 
acrosome and mitochondria of bovine sperm. In addition, we showed that presence of trehalose in medium supplement with FCS provided better protection to bovine sperm than the medium with FCS alone. The presence of a decondensed sperm head, pronucleus and blastocyst formation after ICSI demonstrated that freeze-dried sperm using EGTA solution and medium supplemented with FCS and trehalose were able to fertilize matured oocytes.

The long-term goal of research on freeze-drying sperm is to preserve its motility and fertilizing capability, enabling the sperm to subsequently be used in Al or IVF. However, this goal has not been achieved in any of the species studied. As expected, in the present investigation, sperm were immotile after freeze-drying in all treatments. Indeed, damage to the sperm plasma membrane of all cells analyzed was verified by exclusion stain and confirmed by electron microscopy. In that regard, the plasma membrane is highly susceptible to damage, due to loss of water during dehydration. According to Crowe et al. [20], water loss from phospholipid headgroups in cell membranes may lead to lateral phase separation and cause extravasation of intracellular contents.

The acrosome is another sperm component that has been widely reported to be substantially damaged during the freeze-drying process. However, $>75 \%$ of the sperm had an intact acrosome, regardless of the medium used. The lower percentage $(P<0.05)$ of cells with an intact acrosome in Treatments 1 and 3 (75 and 85\%) suggested that the protection of the acrosome structure was less pronounced when FCS and EGTA solution were present in the lyophilization. Although there is no report in cattle, the results of the present study differed from those described in mice [7] and rabbits [8] and are similar to those in rats [21]. It is important to point out that electron microscopy confirmed that the acrosome was not lost and no changes in its morphology were detected freeze-dried sperm as well as in the control group ( Fig. 1A and $\mathrm{E}$ ). We inferred that the presence of protective media during freeze-drying provided higher acrosome retention and minimized morphological alterations.

Separation of the tail from the head of the lyophilized sperm has been mentioned as a common finding in sperm from pigs [9], rabbits [8] and in mice when Dulbecco's Modified Eagle Medium (DMEM) [7] or EGTA medium [13] and [14] was used. Although there were slight differences among media used, in general we observed a low degree of head-tail separation. Media containing trehalose and EGTA had the lowest rate of tail separation. Perhaps bovine sperm has a greater stability in the connection region than other species, which could account for the low rate of loss of tail after freeze-drying when compared to data from other species. Based on electron microscopy, in all treatments the mitochondria were preserved (Fig. 1C) after freeze-drying, however, microtubules remained intact only in the media containing FCS and in the control group (Table 2; Fig. 1B and F). Therefore, we 
hypothesize that the media with EGTA and trehalose, due to their hypertonicity, could affect microtubule integrity.

Although the objective of freeze-drying was to completely preserve structural and functional sperm characteristics, an intact sperm nucleus is the essential prerequisite for successful embryo development [7] and [14]. Mammalian sperm nuclei are very stable and highly condensed with a unique DNA organization [22], 6-fold more compact and 40-fold lower DNA volume than somatic cells [23] and [24]. This unique DNA packing is essential to protect the cell and minimize damages caused by exogenous agents before fertilization. It has been suggested that the bovine sperm have a more stable nuclear packing than other species [25]. Although this has caused some difficulties for sperm head decondensation in the ooplasm when bovine sperm are used for ICSI, it facilitates preservation of bovine sperm by freezedrying.

Sperm DNA can be damaged during freeze-drying and especially during storage if the adequate protection is not provided. It is well known that DNA damage can be caused by activation of endogenous nucleases, which always occurs after freeze-drying. In the present investigation, DNA damage during freeze-drying and storage were evaluated by TUNEL. Sperm preserved in media containing trehalose and EGTA stored for 3 months at $4{ }^{\circ} \mathrm{C}$ had lower sperm DNA fragmentation than the medium containing FCS.

It was not known why sperm agglutination occurred in the medium with EGTA; although it hindered the manipulation in ICSI, it did not affect the results. Therefore, the nuclear function of freeze-dried sperm (evaluated by ICSI) corroborated the structural evaluation by TUNEL; sperm lyophilized with media containing EGTA or trehalose had the highest rates of sperm head decondensation, formation of a pronucleus, and production of a blastocyst (Table 3 and Table 4).

Although solutions containing EGTA or trehalose adequately preserved bovine sperm viability during the freeze-drying process, the mechanism and function of these solutions in protecting the sperm are not clear. It is believed that EGTA, a calcium chelator, either prevents or decreases the activity of calcium-dependent endonucleases [14] by limiting the availability of the circulating calcium; therefore, EGTA is recommended to minimize chromosome breakage [26]. Conversely, trehalose, a disaccharide of glucose is present in many organisms that are able to survive complete dehydration, a phenomenon known as anhydrobiosis [20] and [27]. It is hypothesized that during sperm freeze-drying, trehalose binds to the sperm membranes and makes them more stable (reduced molecular mobility), which would increase biological stability. Another possibility is that trehalose could replace the water and cause stabilization due to the formation of hydrogen bridges with components of the cells when the 
water is removed [28]. Therefore, trehalose has been successfully used to protect liposomes [29], bacteria [30], yeast [31], retroviruses [32], proteins [33], chromatin [34], and cell lines in vitro [35], [36] and [37].

In conclusion, we demonstrated that the medium TCM 199 with Hanks salts supplemented with FCS and $0.2 \mathrm{M}$ of trehalose and the medium containing EGTA solution were more efficient in avoiding damage to components of bovine sperm, especially the nuclei. Therefore, the medium used for freeze-drying process directly affected sperm nuclear integrity. Considering the beneficial effects of trehalose and EGTA, perhaps a combination of the two would confer even better protection to sperm during the freeze-drying and especially during storage.

Acknowledgements

The authors thank Embrapa Genetics Resources and Biotechnology, CNPq, and FINEP for financial support.

\section{References}

[1] Keskintepe L, Pacholczyk G, Machnicka A, Norris K, Curuk MA, Khan I, et al. Bovine blastocyst development from oocytes injected with freeze-dried spermatozoa. Biol Reprod 2002;67:409-15.

[2] Kusakabe $\mathrm{H}$, Kamiguchi $\mathrm{Y}$. Chromosomal integrity of freezedried mouse spermatozoa after 137Cs gamma-ray irradiation. Mutat Res 2004;556:163-8.

[3] Polge C, Smith AU, Parkes AS. Revival of spermatozoa after vitrification and dehydration at low temperature. Nature 1949;164:666-7.

[4] Sherman JK. Freezing and freeze-drying of human spermatozoa. Fertil Steril 1954;5:357-71.

[5] Bialy G, Smith VR. Freeze-drying of bovine spermatozoa. J Dairy Sci 1957;40:739-45.

[6] Yushchenko NP. Proof of the possibility of preserving mammalian spermatozoa in a dried state. Proc Lenin Acad Agr Sci 1957;22:37-40.

[7] Wakayama T, Yanagimachi R. Development of normal mice from oocytes injected with freeze-dried spermatozoa. Nat Biotechnol 1998;16:639-41.

[8] Liu JL, Kusakabe H, Chang CC, Suzuki H, Schmidt DW, Julian M, et al. Freeze-dried sperm fertilization leads to full-term development in rabbits. Biol Reprod 2004;70:1776-81.

[9] Kwon IK, Park KE, Niwa K. Activation, pronuclear formation, and development in vitro of pig oocytes following intracytoplasmic injection of freeze-dried spermatozoa. Biol Reprod 2004;71:1430-6. 
[10] Critser JK, Huse-Benda AR, Aaker DV, Arneson BW, Ball GD. Cryopreservation of human spermatozoa. I. Effects of holding procedure and seeding on motility, fertilizability, and acrosome reaction. Fertil Steril 1987;47:656-63.

[11] Oates RD, Lobel SM, Harris DH, Pang S, Burgess CM, Carson RS. Efficacy of intracytoplasmic sperm injection using intentionally cryopreserved epididymal spermatozoa. Hum Reprod 1996;11:133-8.

[12] Wakayama T, Whittingham DG, Yanagimachi R. Production of normal offspring from mouse oocytes injected with spermatozoa cryopreserved with or without cryoprotection. J Reprod Fertil 1998;112:11-7.

[13] Kaneko T, Whittingham DG, Yanagimachi R. Effect of $\mathrm{pH}$ value of freeze-drying solution on the chromosome integrity and developmental ability of mouse spermatozoa. Biol Reprod 2003;68:136-9.

[14] Kusakabe H, Szczygiel MA, Whittingham DG, Yanagimachi R. Maintenance of genetic integrity in frozen and freeze-dried mouse spermatozoa. Proc Natl Acad Sci USA 2001;98:13501-6.

[15] McGinnis LK, Zhu L, Lawitts JA, Bhowmick S, Toner M, Biggers JD. Mouse sperm desiccated and stored in trehalose medium without freezing. Biol Reprod 2005;73:627-33.

[16] Cormier N, Sirad MA, Bailey JL. Premature capacitation of bovine spermatozoa is initiated by cryopreservation. J Androl 1997;18:461-8.

[17] Parrish JJ, Krogenaes A, Susko-Parrish JL. Effect of bovine sperm separation by either swim-up and percoll method on success of in vitro fertilization and early embryonic development. Theriogenology 1995;44:859-69.

[18] Didion BA, Dobrinsky JR, Giles JR, Graves CN. Staining procedure to detect viability and the true acrosome reaction in spermatozoa of various species. Gamete Res 1989;22: 51-7.

[19] Holm P, Booth PJ, Schmidt MH, Greve T, Callesen H. High bovine blastocyst development in a static in vitro production system using SOFaa medium supplemented with sodium citrate and myo-inositol with or without serum proteins. Theriogenology 1999;52:683-700.

[20] Crowe JH, Crowe LM, Carpenter JF, Prestelski SJ, Hoekstra FA. Anhydrobiosis: cellular adaptations to extreme dehydration. In: Dantzler WH, editor. Comparative Physiology Handbook of Physiology, vol. II. Oxford: Oxford University Press; 1997. p. 1445-77.

[21] Hirabayashi $M$, Kato $M$, Ito J, Hochi S. Viable rat offspring derived from oocytes intracytoplasmically injected with freezedried sperm heads. Zygote 2005;13:79-85.

[22] Yanagimachi R. Stability of the mammalian sperm nucleus. Zygote 1994;2:383-4.

[23] Ward WS. The structure of the sleeping genome: implication of sperm DNA organization for somatic cells. J Cell Biochem 1994;55:77-82.

[24] Ward WS, Zalensky AO. The unique complex organization of the transcriptionally silent sperm chromatin. Crit Rev Eukaryot Gene Expr 1996;6:139-47. 
[25] Perreault SD, Barbee RR, Elstein KH, Zucker RM, Keefer CL. Interspecies differences in the stability of mammalian sperm nuclei assessed in vivo by sperm microinjection and in vitro by flow cytometry. Biol Reprod 1988;39:157-67.

[26] Szczygiel MA, Moisyadi S, Ward WS. Expression of foreign DNA is associated with paternal chromosome degradation in intracytoplasmic sperm injection-mediated transgenesis in the mouse. Biol Reprod 2002;68:1903-10.

[27] Crowe JH, Hoekstra FA, Crowe LM. Anhydrobiosis. Ann Rev Physiol 1992;54:579-99.

[28] Blanquet S, Garrait G, Beyssac E, Perrier C, Denis S, Hebrard G, et al. Effects of cryoprotectants on the viability and activity of freeze dried recombinant yeasts as novel oral drug delivery systems assessed by an artificial digestive system. Eur J Pharm Biopharm 2005;61:32-9.

[29] Crowe LM, Crowe JH, Rudolph A, Womersley C, Appel L. Preservation of freeze dried liposomes by trehalose. Arch Biochem Biophys 1985;242:240-7.

[30] Conrad PB, Miller DP, Cielenski PR, de Pablo JJ. Stabilization and preservation of Lactobacillus acidophilus in saccharide matrices. Cryobiology 2000;41:17-24.

[31] Leslie SB, Teter SA, Crowe LM, Crowe JH. Trehalose lowers membrane phase transitions in dry yeast cells. Biochim Biophys 1994;1192:7-13.

[32] Bieganski R, Fowler A, Morgan JR, Toner M. Stabilization of active recombinant retroviruses in an amorphous dry state with trehalose. Biotechnol Prog 1998;14:615-20.

[33] Kaushik JK, Bhat R. Why is trehalose an exceptional protein stabilizer? An analysis of the thermal stability of proteins in the presence of the compatible osmolyte trehalose. J Biol Chem 2003;278:26458-65.

[34] Gilles R, Bourdouxhe-Housiaux C, Colson P, Houssier C. Effect of compensatory organic osmolytes on resistance to freezedrying of $\mathrm{L} 929$ cells and of their isolated chromatin. Comp Biochem Physiol A Mol Integr Physiol 1999;122: 145-55.,

[35] Crowe JH, Tablin F, Wolkers WF, Gousset K, Tsvetkova NM, Ricker J. Stabilization of membranes in human platelets freezedried with trehalose. Chem Physiol Lipids 2003;22:4152.

[36] Guo N, Puhlev I, Brown DR, Mansbridge J, Levine F. Trehalose expression confersdesiccation tolerance on human cells. Nat Biotechnol 2000;18:168-71.

[37] Puhlev I, Guo N, Brown DR, Levine F. Desiccation tolerance in human cells. Cryobiology 2001;42:207-17. 